\title{
STRATEGI PEMBERDAYAAN MENINGKATKAN IKLIM ORGANISASI PERAWAT PELAKSANA DI RUMAH SAKIT
}

\author{
Noraliyatun Jannah ${ }^{1,2 *}$, Hanny Handiyani ${ }^{3}$, Hening Pujasari ${ }^{3}$ \\ 1. PSIK, Fakultas Kedokteran, Universitas Syiah Kuala Darussalam, Banda Aceh 23111, Indonesia \\ 2. Program Studi Magister, Fakultas Ilmu Keperawatan, Universitas Indonesia, Depok 16424, Indonesia \\ 3. Fakultas Ilmu Keperawatan, Universitas Indonesia, Depok 16424, Indonesia \\ *E-mail: norajannatin@gmail.com
}

\begin{abstract}
Abstrak
Iklim organisasi dipengaruhi oleh pemberdayaan. Tujuan penelitian cross sectional ini untuk mengetahui hubungan struktur pemberdayaan dengan iklim organisasi perawat pelaksana di suatu rumah sakit di Depok, Jawa Barat. Hasil penelitian pada 101 perawat pelaksana (total sampling) menggunakan dua instrumen (CWEQ-II dan OCQ) menunjukkan mayoritas perawat mempersepsikan struktur pemberdayaan cenderung rendah sedangkan iklim organisasi cenderung baik. Uji Chi Square membuktikan struktur pemberdayaan (kesempatan, informasi, dukungan, sumber daya, kekuatan formal, kekuatan informal) berhubungan dengan iklim organisasi $(p=0,000-0,031 ; \alpha=0,05)$. Faktor yang paling berpengaruh pada iklim organisasi dalam penelitian ini adalah dimensi kekuatan informal, sehingga perlu ditingkatkan di rumah sakit tersebut. Perawat manajer perlu memiliki keterampilan kepemimpinan dalam pemberdayaan perawat pelaksana untuk meningkatkan iklim organisasi dan pelayanan keperawatan.
\end{abstract}

Kata kunci: iklim organisasi, pemberdayaan, perawat

\begin{abstract}
Empowerment Strategy Improving Organizational Climate of Staff Nurse at the Hospital. Organizational climate is affected by empowerment. This cross sectional research aimed to investigate the relationship between structural empowerment and organizational climate of nurses at a hospital in Depok, West Java. The results from 101 nurses using two instruments (CWEQ-II and OCQ) showed that majority of the nurses perceived that the structural empowerment tended to be low while the organizational climate was already in a good condition. Statistical tests using Chi Square showed a relationship between structural empowerment (opportunity, information, support, resource, formal power, informal power) and organizational climate $(p=0.000-0.03 ; \alpha=0.05)$. Moreover, the most influential factor on the organizational climate was the dimension of the informal power, therefore this factor should be strengthened in the hospital. It is suggested that the nurse manager is expected to have empowerment leadership skill to enhance the organizational climate and nursing services.
\end{abstract}

Keywords: empowerment, nurse, organizational climate

\section{Pendahuluan}

Iklim organisasi perawat di rumah sakit mempengaruhi hasil pelayanan kesehatan terhadap pasien. Strategi pemberdayaan dapat menciptakan lingkungan kerja yang positif bagi perawat di rumah sakit. Salah satu faktor yang mempengaruhi kualitas suatu pelayanan dan profesionalisme perawat adalah iklim organisasi di rumah sakit. Struktur pemberdayaan yang kuat diperlukan suatu organisasi untuk menciptakan iklim organisasi yang kondusif (Hall, 2005; Laschinger, Almost, \& Tuer-Hodes, 2003; Mrayyan, 2008; Norbergh, Hellzen, Sandman, \& Asplun, 2002).

Pemberdayaan dengan iklim organisasi mempunyai hubungan yang saling mempengaruhi. Perawat yang berada dalam lingkungan kerja dengan pemberdayaan menunjukkan kepuasan kerja dan komitmen yang tinggi serta ketegangan 
kerja yang rendah dibandingkan dengan yang tidak mempertimbangkan pemberdayaan dalam lingkungan kerja (Laschinger, Finegan, Shamian, \& Wilk, 2001; Tappen, 2010).

Angka turnover perawat pelaksana di sebuah rumah sakit di Depok sudah mencapai angka lebih dari sepuluh persen di tahun 2009 dan 2010. Penelitian Langitan (2010) tentang faktorfaktor yang mempengaruhi kejadian turnover perawat pelaksana di sebuah rumah sakit di Depok menunjukkan bahwa faktor yang menyebabkan turnover perawat adalah iklim organisasi yang tidak baik. Rumah sakit ini memerlukan suatu strategi manajemen untuk meningkatkan iklim organisasi sehingga diharapkan mampu menekan angka turnover perawat pelaksana. Salah satu upaya untuk menekan dampak dari iklim organisasi yang negatif adalah dengan menggunakan konsep struktur pemberdayaan.

Pemberdayaan merupakan suatu strategi perawat manajer dalam menciptakan pelayanan kesehatan yang efektif dengan memberikan penguatan atau pemberdayaan kepada para staf. Pengaturan perubahan organisasi secara efektif mengharuskan pimpinan perawat memahami proses sosial yang mempengaruhi perilaku pekerja, terutama sekali dengan menyediakan iklim yang kondusif untuk pemberdayaan staf tersebut (Laschinger, et al., 2003; Mok \& Au-Yeung, 2002; Wagner, 2007). Salah satu faktor yang mempengaruhi hasil suatu pelayanan adalah pengalaman perawat terhadap iklim organisasi di tempat kerja. Sebuah rumah sakit di Depok memerlukan strategi untuk meningkatkan lingkungan kerja yang positif bagi karyawan, maka peneliti tertarik menjawab pertanyaan penelitian tentang hubungan struktur pemberdayaan dengan iklim organisasi perawat pelaksana di sebuah rumah sakit di Depok Jawa Barat.

\section{Metode}

Penelitian menggunakan desain analitik observasional dengan pendekatan Cross-Sectional. Instrumen yang digunakan dalam penelitian ini yaitu The Condition for Work Effectiveness Questionnaire II (CWEQ-II) ${ }^{\#}$ yang digunakan untuk mengukur struktur pemberdayaan. Alat ukur ini dikembangkan oleh Laschinger, et al. (2001). Instrumen lainnya adalah The Organizational Climate Questionnaire (OCQ) yang digunakan untuk mengukur iklim organisasi. Alat ukur ini dikembangkan oleh Stringer (2002). Kedua instrumen ini merupakan kuesioner yang sudah baku (standardized questionnaire/gold standard). Responden penelitian adalah total sampling dengan 101 perawat pelaksana di sebuah rumah sakit di Depok.

Peneliti menggunakan teknik penerjemahan kuesioner dengan prosedur translation review by bilingual judges. Teknik ini merupakan bagian dari teknik back translation tetapi menggunakan prosedur yang berbeda karena berfokus pada sasaran dan sumber bahasa.

Proses penerjemahan kuesioner asing dalam penelitian ini dilakukan dengan empat judges, secara teknis meliputi; pada tahap awal dilakukan oleh peneliti, lalu terjemahan diperiksa oleh seorang penerjemah (translator) yang telah mempunyai keahlian dan pengalaman dalam bidang pendidikan bahasa Inggris selama lima belas tahun. Setelah kuesioner diperiksa dan direvisi, peneliti melakukan diskusi dengan penerjemah tersebut. Peneliti juga memeriksakan terjemahan dengan dua orang dosen di bidang keperawatan sebagai seorang ahli dalam ilmu keperawatan dan bahasa Inggris. Selanjutnya, kuesioner yang telah diterjemahkan tersebut direview kembali oleh ahli (expert) di bidang manajemen keperawatan dengan kemampuan dwi bahasa, yaitu seorang profesor keperawatan di Indonesia.

\section{Hasil}

Gambaran iklim organisasi sebuah rumah sakit di Depok secara keseluruhan dipersepsikan perawat pelaksana cenderung baik $(57,4 \%)$. Sedangkan struktur pemberdayaan sebagian besar dipersepsikan perawat pelaksana cenderung rendah, tetapi perbedaan proporsi antara kategori rendah dan tinggi tidak signifikan. Hal ini ditunjukkan dengan jawaban responden bahwa struktur 
pemberdayaan berada pada kategori rendah $(51,5 \%)$ dan tinggi $(48,5 \%)$.

Hasil uji Chi Square menunjukkan ada hubungan yang bermakna antara struktur pemberdayaan dengan iklim organisasi. Seluruh dimensi struktur pemberdayaan yaitu; kesempatan, informasi, dukungan, sumber daya, kekuatan formal, dan kekuatan informal juga berhubungan dengan iklim organisasi $(p \leq 0,05 ; \alpha=0,05)$ (lihat pada Tabel 1).

Model multivariat akhir (Tabel 2) menunjukkan terdapat variabel independen yang paling bermakna yaitu variabel dukungan $(p=0,004 ; \alpha=$
$0,05)$ dan kekuatan informal $(\mathrm{p}=0,015 ; \alpha=0,05)$. Dukungan yang tinggi mempunyai peluang meningkatkan iklim organisasi yang baik 4,8 kali lebih besar dibandingkan dukungan yang rendah. Kekuatan informal yang tinggi berpeluang meningkatkan iklim organisasi yang baik 6,2 kali lebih besar dibandingkan kekuatan informal yang rendah.

Berdasarkan model akhir regresi logistik terlihat bahwa dimensi dari struktur pemberdayaan yang paling berpengaruh terhadap iklim organisasi perawat pelaksana adalah kekuatan informal setelah dikontrol variabel informasi, sumber daya, dan kekuatan formal.

Tabel 1. Hubungan Struktur Pemberdayaan Beserta Dimensinya dengan Iklim Organisasi Perawat Pelaksana

\begin{tabular}{|c|c|c|c|c|c|c|c|c|}
\hline \multirow{3}{*}{ Variabel } & \multicolumn{4}{|c|}{ Iklim Organisasi } & \multirow{2}{*}{\multicolumn{2}{|c|}{ Total }} & \multirow{3}{*}{$\begin{array}{c}\text { OR } \\
(95 \% \mathrm{CI})\end{array}$} & \multirow{3}{*}{$\mathbf{p}$} \\
\hline & \multicolumn{2}{|c|}{ Kurang baik } & \multicolumn{2}{|c|}{ Baik } & & & & \\
\hline & $\mathbf{N}$ & $\%$ & $\mathbf{n}$ & $\%$ & $\mathbf{N}$ & $\%$ & & \\
\hline \multicolumn{9}{|c|}{ Struktur Pemberdayaan } \\
\hline a. Rendah & 32 & 61,5 & 20 & 38,5 & 52 & 100 & 5,527 & \multirow[t]{2}{*}{0,000} \\
\hline b. Tinggi & 11 & 22,4 & 38 & 77,6 & 49 & 100 & $2,3-13,2$ & \\
\hline \multicolumn{9}{|c|}{ Dimensi Kesempatan } \\
\hline a. Rendah & 29 & 65,9 & 15 & 34,1 & 44 & 100 & 5,938 & \multirow[t]{2}{*}{0,000} \\
\hline b. Tinggi & 14 & 24,6 & 43 & 75,4 & 57 & 100 & $2,5-14,1$ & \\
\hline \multicolumn{9}{|c|}{ Dimensi Informasi } \\
\hline a. Rendah & 25 & 69,4 & 11 & 30,6 & 36 & 100 & 5,934 & \multirow[t]{2}{*}{0,000} \\
\hline b. Tinggi & 18 & 27,7 & 47 & 72,3 & 65 & 100 & $2,4-14,5$ & \\
\hline \multicolumn{9}{|c|}{ Dimensi Dukungan } \\
\hline a. Rendah & 31 & 70,5 & 13 & 29,5 & 44 & 100 & 8,942 & \multirow[t]{2}{*}{0,000} \\
\hline b. Tinggi & 12 & 21,1 & 45 & 78,9 & 57 & 100 & $3,6-22,1$ & \\
\hline \multicolumn{9}{|c|}{ Dimensi Sumber daya } \\
\hline a. Rendah & 28 & 53,8 & 24 & 46,2 & 52 & 100 & 2,644 & \multirow[t]{2}{*}{0,031} \\
\hline b. Tinggi & 15 & 30,6 & 34 & 69,4 & 49 & 100 & $1,1-5,9$ & \\
\hline \multicolumn{9}{|c|}{ Dimensi Kekuatan formal } \\
\hline a. Rendah & 31 & 63,3 & 18 & 36,7 & 49 & 100 & 5,741 & \multirow[t]{2}{*}{0,000} \\
\hline b. Tinggi & 12 & 23,1 & 40 & 76,9 & 52 & 100 & $2,4-13,6$ & \\
\hline \multicolumn{9}{|c|}{ Dimensi Kekuatan informal } \\
\hline a. Rendah & 35 & 66,0 & 18 & 34,0 & 53 & 100 & 9,722 & \multirow[t]{2}{*}{0,000} \\
\hline b. Tinggi & 8 & 16,7 & 40 & 83,3 & 48 & 100 & $3,7-25,0$ & \\
\hline
\end{tabular}

Tabel 2. Pemodelan Multivariat Akhir untuk Hubungan antara Lama Kerja, Informasi, Dukungan, Sumber Daya, Kekuatan Formal, Kekuatan Informal dengan Iklim Organisasi Perawat Pelaksana

\begin{tabular}{lcccc}
\hline \multicolumn{1}{c}{ Variabel } & \multirow{2}{*}{ Wald } & \multirow{2}{*}{ OR } & \multicolumn{2}{c}{ 95\% CI } \\
\cline { 3 - 5 } & & & Lower & Upper \\
\hline Dukungan & $\mathbf{0 , 0 0 4}$ & 4,823 & 1,636 & 14,217 \\
Kekuatan informal & $\mathbf{0 , 0 1 5}$ & 6,268 & 1,436 & 27,355 \\
Kekuatan formal & 0,656 & 1,401 & 0,318 & 6,178 \\
Sumber daya & 0,404 & 0,501 & 0,099 & 2,538 \\
Informasi & 0,187 & 2,202 & 0,681 & 7,116 \\
\hline
\end{tabular}




\section{Pembahasan}

Hasil penelitian menunjukkan bahwa ada hubungan yang bermakna antara struktur pemberdayaan dengan iklim organisasi perawat pelaksana di sebuah rumah sakit di Depok. Begitu pula untuk setiap sub variabel struktur pemberdayaan yang terdiri dari enam dimensi; kesempatan, informasi, dukungan, sumber daya, kekuatan formal, dan kekuatan informal juga menunjukkan adanya hubungan yang bermakna dengan iklim organisasi. Semakin tinggi persepsi pemberdayaan perawat pelaksana semakin besar pula peluang terciptanya iklim organisasi yang baik dibanding perawat pelaksana dengan persepsi pemberdayaan yang rendah.

Hasil penelitian ini mendukung teori Kanter (1993) bahwa struktur pemberdayaan organisasi di tempat kerja memegang peranan penting dalam membentuk dan meningkatkan kualitas kerja karyawan pada suatu organisasi. Kanter menemukan teori bahwa lingkungan kerja yang menyediakan akses informasi, sumber, dukungan, dan kesempatan untuk belajar dan berkembang, juga pemberdayaan kekuatan formal dan informal merupakan suatu pemberdayaan (Laschinger, 1996; Nedd, 2006; Stewart, McNulty, Griffin, \& Fitzpatrick, 2010).

Perawat mempunyai kesempatan yang sudah baik untuk berkembang di sebuah rumah sakit di Depok. Akses terhadap informasi, rencana strategis, dan nilai-nilai dari pihak manajemen keperawatan sudah baik. Dukungan yang didapatkan dari pimpinan/manajer dan akses kekuatan formal oleh perawat pelaksana meliputi; penghargaan untuk inovasi pekerjaan, fleksibilitas pekerjaan, dan jumlah pekerjaan yang tampak oleh orang lain juga baik. Tapi akses terhadap sumber daya, yaitu kemampuan untuk memperoleh alat berupa uang, materi, waktu, dan persediaan yang dibutuhkan untuk melakukan pekerjaan cenderung rendah. Begitu pula dengan kekuatan informal masih rendah, yaitu pada hubungan kolaborasi dengan profesi dokter, teman sejawat, tenaga kesehatan lain, dan perawat manajer.
Keenam akses tersebut berhubungan dengan iklim organisasi yang cenderung dipersepsikan baik oleh perawat. Pemberdayaan yang secara umum dipersepsikan cenderung rendah berhubungan dengan persepsi tentang iklim organisasi yang baik. Artinya, bila persepsi perawat pelaksana semakin baik terhadap struktur pemberdayaan rumah sakit akan tercipta iklim organisasi yang semakin baik pula. Saat iklim organisasi maksimal, perawat juga akan memberikan pelayanan yang lebih baik kepada klien di rumah sakit.

Hasil penelitian juga menempatkan struktur pemberdayaan sebagai suatu strategi kepemimpinan perawat. Teori pemberdayaan telah banyak dipakai dalam penelitian di bidang perilaku organisasi karena berguna untuk membentuk berbagai intervensi organisasi untuk meningkatkan kondisi kerja dalam lingkungan keperawatan (Laschinger, 1996; Laschinger, et al., 2001; Laschinger \& Finegan, 2005; Laschinger, Wong, \& Greco, 2006; Nedd, 2006). Pemberdayaan di tempat kerja sebagai strategi manajemen telah menunjukkan kesuksesan dalam menciptakan lingkungan kerja yang positif dalam organisasi berdasarkan banyak penelitian (Laschinger, et al., 2006; Laschinger, Finegan, \& Wilk, 2009; Manojlovich, 2007).

Pimpinan rumah sakit dan perawat manajer perlu memperhatikan iklim organisasi yang kondusif melalui pemberdayaan bagi pekerja dalam upaya mengubah organisasi menuju pelayanan kesehatan yang lebih baik. Pimpinan dan pekerja saling mempengaruhi dalam terciptanya suatu iklim organisasi. Hubungan yang positif antara supervisor, tim, dan persepsi pekerja tentang bagaimana iklim organisasi menentukan suatu perubahan yang kondusif (Li, 2008). Perilaku pimpinan menggerakkan iklim, lalu menimbulkan motivasi. Motivasi yang timbul merupakan penggerak terbesar dalam bottom-line performance. Stringer (2002) menempatkan kepemimpinan penting dalam menciptakan iklim organisasi. Penelitian menunjukkan bahwa kepemimpinan mempunyai dampak yang besar terhadap iklim. Kepemimpinan 
juga merupakan elemen yang menentukan dalam merubah suatu iklim.

Perawat manajer perlu mempunyai keterampilan kepemimpinan dalam pemberdayaan. Perawat dalam menciptakan pelayanan kesehatan yang efektif saat ini memerlukan keterampilan kepemimpinan yang mampu memberikan penguatan pada lingkungannya. Strategi ini perlu dipelajari dan dijadikan model bagi manajer dan pimpinan untuk mempromosikan pengembangan perilaku pemberdayaan untuk bawahan (Gunden \& Crissman, 1992), sebagaimana perubahan lingkungan merupakan bagian dari kepemimpinan dan organisasi (Feldman, 2003). Pengembangan perilaku pemberdayaan tersebut juga dapat diterapkan pada setiap individu perawat yang merupakan front liners dalam pemberian pelayanan kesehatan untuk menunjukkan kekuatan melalui keterampilan keperawatan yang dimiliki. Jika hal ini diaplikasikan dengan baik, peran perawat sebagai tenaga kesehatan dengan proporsi terbesar di Indonesia akan tampak lebih signifikan dalam pembangunan kesehatan bangsa.

Variabel yang paling besar pengaruhnya terhadap kejadian iklim organisasi yang baik adalah variabel kekuatan informal. Kekuatan informal yang tinggi berpeluang meningkatkan iklim organisasi yang baik enam kali lebih besar dibandingkan kekuatan informal yang cenderung rendah. Artinya, bila kekuatan informal ini dapat ditingkatkan tentu mampu meningkatkan iklim organisasi di sebuah rumah sakit di Depok.

Kekuatan informal berasal dari jaringan pekerja, aliansi interpersonal, hubungan dengan atau di luar organisasi. Informal level dari organisasi meliputi segala sesuatu yang tidak tertulis, hubungan yang tidak merefleksikan struktur dalam organisasi, meliputi norma, tradisi tentang bagaimana orang bekerja bersama, dan mempunyai pengaruh yang kuat terhadap apa yang terjadi dalam organisasi (Tappen, 2010). Kekuatan informal diturunkan dari koneksi sosial, perkembangan saluran komunikasi, dan informasi dari sponsor, peers, subordinate, dan kelompok lintas fungsi (Kanter, 1993; Laschinger, et al., 2001).
Pekerja dan kepemimpinan organisasi dapat dipengaruhi oleh kekutan informal. Informal level dapat menyediakan dukungan bagi orang di organisasi yang gagal didukung oleh level formal. Kekuatan informal juga dapat mengurangi keefektifan organisasi saat pekerja sepakat untuk membatasi pekerjaan dan memberi tekanan pada pekerja yang lain (Tappen, 2010). Postulat teori Kanter menyatakan pemimpin mengembangkan pemberdayaan dari sumber formal dan informal dalam sistem organisasi.

Kekuatan informal yang datang dari hubungan dan aliansi dengan orang-orang merupakan mediator penting dari kekuatan formal. Selanjutnya, kekuatan informal juga sangat penting dalam kepemimpinan strategis. Teori Kanter menyatakan bahwa nurse leaders yang mempunyai aliansi informal merasakan punya akses untuk sumber daya, dukungan, dan fungsi dalam kerja (Huber, 2006). Nurse leaders dengan kekuatan formal dan informal berhasil memberikan akses terhadap pemberdayaan staf (Upenieks, 2002).

Pola hubungan perawat dengan manajer keperawatan, teman sejawat, profesi dokter, dan tenaga kesehatan lain merupakan kekuatan informal di sebuah rumah sakit di Depok dalam penelitian ini. Dimensi ini cenderung rendah tetapi dapat memberikan pengaruh yang besar pada terciptanya iklim organisasi yang secara umum sudah baik di rumah sakit yang dimaksud. Temuan ini didukung oleh penelitian Upenieks (2002) yang menyatakan pentingnya kekuatan informal dalam suatu organisasi. Dalam penelitian kualitatif tersebut ditemukan bahwa nurse leaders merasakan kekuatan formal dapat menjadi penghambat efektifitas kerja, dan karenanya musti membangun hubungan dengan yang lainnya, yaitu kekuatan informal dalam organisasi untuk memperbesar pemberdayaan.

Hasil penelitian ini berkaitan dengan pernyataan Jones (2007) bahwa setiap organisasi mempunyai struktur informal yang mampu atau tidak mampu menyediakan suasana kepemilikan bagi anggota organisasi, hal ini dirasakan sebagai suatu iklim. Struktur informal dimiliki oleh 
semua organisasi yang tidak teridentifikasi pada bagan organisasi. Struktur yang dimaksud terdiri dari jaringan sosial dan hubungan yang dibangun dalam pengaturan kerja. Organisasi mempunyai struktur tersembunyi yang tidak ditunjukkan pada bagan organisasi. Didefinisikan dengan pola, perilaku, dan interaksi lebih daripada personal dibanding hubungan kerja. Upenieks (2002) mendefinisikan organisasi informal memberi penekanan pada orang-orang dan hubungan mereka, sedangkan organisasi formal memberi penekanan pada posisi jabatan.

Pada praktik di sebuah rumah sakit di Depok, kekuatan informal dapat ditingkatkan misalnya melalui pertemuan formal dan informal para karyawan, pemanfaatan fasilitas pesan singkat telpon selular untuk penyampaian informasi dan reward. Hal ini terlihat sederhana tetapi mampu mempercepat aliran informasi ke seluruh perawat pelaksana. Hasil penelitian yang menyatakan bahwa dimensi kekuatan informal merupakan faktor yang paling berhubungan dengan struktur pemberdayaan merupakan temuan menarik di bidang perilaku organisasi sehingga dapat diteliti lebih lanjut untuk mengembangkan penemuan di area manajemen keperawatan rumah sakit di Indonesia.

\section{Kesimpulan}

Struktur pemberdayaan berhubungan dengan iklim organisasi perawat pelaksana. Kekuatan informal merupakan dimensi struktur pemberdayaan yang memberi pengaruh paling dominan terhadap peningkatan iklim organisasi perawat pelaksana di sebuah rumah sakit di Depok. Penelitian lebih lanjut tentang kekuatan informal perlu dikembangkan untuk menemukan kaitannya dengan realitas sosial/sosiologis pada bidang perilaku organisasi dalam penyelenggaraan pelayanan kesehatan/keperawatan.

Perawat perlu memiliki keterampilan kepemimpinan dalam pemberdayaan (empowering leadership skill) baik sebagai perawat manajer maupun sebagai individu. Keterampilan ini dapat dipraktikkan oleh perawat manajer dengan memberikan penguatan atau pemberdayaan terhadap perawat pelaksana pada enam dimensi struktur pemberdayaan; kesempatan, informasi, dukungan, sumber daya, kekuatan formal, dan kekuatan informal. Perawat sebagai individu juga perlu terus memelihara dan meningatkan ilmu serta keterampilan keperawatan yang dimiliki sebagai suatu kekuatan. Kedua hal ini diharapkan mampu meningkatkan peran perawat sebagai front liners dalam pemberian pelayanan kesehatan.

Secara teori pengukuran untuk variabel iklim organisasi dapat juga dilakukan dengan memecah variabel tersebut dalam beberapa sub variabel sehingga pembahasan serta solusi untuk iklim organisasi menjadi lebih kaya dan spesifik. Peneliti tidak melakukan hal tersebut karena jumlah sampel tidak memenuhi untuk dianalisis multivariat bila variabel iklim organisasi dipecah sebagaimana struktur pemberdayaan (MS, RR, INR).

\section{Referensi}

Feldman, H.R. (Ed.). (2003). The nursing shortage: Strategies for recruitment and retention in clinical practice and education. New York: Springer Publishing Co.

Gunden, E. \& Crissman, S. (1992). Leadership skills for empowerment. Nursing Administration Quarterly Journal, 16 (3), 6-10.

Hall, L.M. (Ed.). (2005). Quality work environment for nurse and patient safety. Burlington: Jones \& Bartlett Publisher, Inc.

Huber, D. (2006). Leadership and nursing care management (3rd Ed.). Philadelphia: Elsevier Health Sciences.

Jones, R.A.P. (2007). Nursing leadership and management: Theories, processes, and practice. Philadelphia: F.A. Davis Co.

Kanter, R.M. (1993). Men and women of the corporation (2nd Ed.). New York: Basic Books.

Langitan, R.E. (2010). Faktor-faktor yang mempengaruhi kejadian turnover perawat 
pelaksana di sebuah rumah sakit di Depok Jawa Barat tahun 2009. (Tesis, tidak dipublikasikan). Program Magister FIK UI, Jakarta

Laschinger, H.K.S. (1996). A theoretical approach to studying work pemberdayaan in nursing: A review of studies testing Kanter's theory of structural power in organizations. Nursing Administration Quarterly Journal, 20 (2), 2541.

Laschinger, H.K.S., Finegan, J., Shamian, J., \& Wilk, P. (2001). Impact of structural and psychological empowerment on job strain in nursing work settings. Journal of Nursing Administration, 31 (5), 260-272.

Laschinger, H.K.S., Almost, J., \& Tuer-Hodes, D. (2003). Workplace empowerment \& magnet hospital characteristics: Making the link. Journal of Advanced Nursing, 33 (7/8), 410422.

Laschinger, H.K.S., \& Finegan, J. (2005). Empowering nurses for work engagement and health in hospital settings. Journal of Nursing Administration, 35 (10), 439-449.

Laschinger, H.K.S., Wong, C.A., \& Greco, P. (2006). The impact of staff nurse empowerment on person-job fit and work engangement/burnout. Nursing Administration Quarterly Journal, 30 (4), 358-367.

Laschinger, H.K.S., Finegan, J., \& Wilk, P. (2009). Context matters: the impact of unit leadership and empowerment on nurses organizational commitment. Journal of Nursing Administration, 39 (5), 228-235.

Li, T.C. (2008). Assessing organizational climate $\&$ leadership as a means to evaluate potential for organizational change. The Journal of Human Resource \& Adult Learning, 4 (1), 47-56.

Manojlovich, M. (2007). Power \& empowerment in nursing: Looking backward to inform the future. Online J Issues Nurs, 12 (1), 2.
Mok, E. \& Au-Yeung, B. (2002). Relationship between organizational climate \& empowerment of nurses in Hong Kong. Journal of Nursing Management, 10, 129-137.

Mrayyan, M.T. (2008). Hospital organizational climates \& nurses' intent to stay: Differences between units \& wards. Contemporary Nurse, 27 (2), 223-236.

Nedd, N. (2006). Perceptions of empowerment and intent to stay. Nursing Economics, 24 (1), 1318.

Norbergh, K.G., Hellzen, O., Sandman, P.O., \& Asplun, K. (2002). Climate and content of daily life for people with dementia living in a group dwelling. Journal of Clinical Nursing, 11 (2), 237-246.

Stewart, J.G., McNulty, R., Griffin, M.T.Q., \& Fitzpatrick, J.J. (2010). Psychological empowerment \& structural empowerment among nurse practitioners. Journal of the American Academy of Nurse Practitioners, 22 (1), 27-34.

Stringer, R.A. (2002). Leadership \& organizational climate: The cloud chamber effect. New Jersey: Pearson Education, Inc.

Tappen, R.M., Whitehead, D.K., \& Weiss, S.A. (2010). Nursing leadership and management: Concepts and practice ( $5^{\text {th }}$ Ed.). Philadelphia: F.A. Davis Co.

Upenieks, V.V. (2002). What constitutes successful nurse leadership? A qualitative approach utilizing Kanter's theory of organizational behavior. Journal of Nursing Administration, 32 (12), 622-632.

Wagner, C.M. (2007). Organizational commitment as a predictor variable in nursing turnover research: literature review. JAN, 60 (3), 235247. 